\title{
Deer Mouse Consumption of Bitterbrush Seed Treated with Four Repellents
}

\author{
RICHARD L. EVERETT AND RICHARD STEVENS
}

\section{Abstract}

Bitterbrush (Purshia tridentata) seeds were treated with one of four repellents-Mestranol, R55, Red Squill, or Alphanaphthylthiourea (ANTU) - and offered to caged deer mice (Peromyscus maniculatus). ANTU reduced deer mouse consumption of bitterbrush seed the most (up to $90 \%$ ) and was not toxic to germinating seed. Deer mice consumed even less ANTU treated seed when seed was first soaked in a $3 \%$ thiourea solution to hasten germination. Although ANTU did not reduce seed consumption of treated bitterbrush seed ( $\widetilde{\boldsymbol{x}} \simeq \mathbf{5 5}$ seed consumed/mouse/night) as much as $0.5 \%$ or $1 \%$ Endrin $(\bar{x} \simeq 35-29$ seed consumed $/$ mice/night), this may not be relevant as Endrin is banned in Canada and subject to severe use restrictions on federal lands in the United States.

Rodent consumption of planted bitterbrush seed has hindered the establishment of this valuable browse species (Holmgren and Basile 1959; Brown and Martinsen 1959). In a planting test reported by Nord (1965), 87\% of planted bitterbrush seed was taken by rodents. Casebeer (1954) identified deer mice as the major consumer of planted bitterbrush seed.

Coating seed with a repellent ${ }^{1}$ is one way to reduce deer mouse predation of bitterbrush seed. A seed repellent is defined here as a chemical that, under the test conditions, causes avoidance of treated seed by a majority of animals before a lethal dosage is ingested. As toxicity of chemicals varies among individual test animals and under different environmental conditions, the distinction between toxicant and repellent is sometimes arbitrary.

In the past, the repellent Endrin ${ }^{2}$ and experimental compound tetramine were used effectively to reduce predation of planted bitterbrush seed (Casebeer 1954; Kverno and Hartwell 1957). Potential danger to workers or nontarget species has, however, resulted in restricted use of these chemicals or banned them entirely on federal lands in the United States and all of Canada (Evans 1974, Fraser 1973).

Alternative repellents to Endrin that reduce conifer seed predation and appear relatively nonhazardous to nontarget animal species have been researched. Four repellents that have reduced deer mouse consumption of conifer seed are: Mestranol, a derivative of

\footnotetext{
Authors are range scientist, USDA Forest Service, Intermountain Forest and Range Experiment Station, Ogden, Utah 84401 , stationed at Renewable Resources Center, University of Nevada Reno; research wildlife biologist, Utah Division of Wildlife Resources, stationed at Ephraim, Utah.

Preparation of this publication was supported by funds provided by the Intermountain Forest and Range Experiment Station, federal programs for Wildlife Restoration W-82-R. Nevada Agricultural Experiment Station Journal Series No. 401.

The authors wish to express appreciation for advice provided by Robert B. Ferguson, Shrub Sciences Laboratory, Provo, Utah, and Rex E. Marsh, University of California, Davis, California. Materials and facilities for the study were provided by W. Darrell Foote, University of Nevada, Agricultural Experiment Station, and George Tsukumoto, Nevada Department of Fish and Game, Reno, Nevada.

Manuscript received January $16,1980$.
}

'This publication reports research involving pesticides used as repellents. It does no contain recommendations for their use, nor does it imply that the uses discussed here have been registered. All uses of pesticides must be registered by appropriate State and/or Federal agencies before they can be recommended.

${ }^{2}$ The use of trade, firm, or corporation names in this publication is for the information and convenience of the reader. Such use does not constitute an official endorsement or approval by the U.S. Department of Agriculture of any product or service to the exclusion of others which may be suitable. estrone-produced by Syntex Corp. (Lindsey et al. 1974); R55, a thiocarbonate derivative-produced by Phillips Petroleum Corp. (Radvanyi 1970); Red Squill, Rodenticide Bait Concentrate 1901 - produced by McLaughlin Gromly King Corp. (Hood 1975, personal communication); and Alpha-naphthylthiourea (ANTU), a derivative of thiourea-produced by Tridom Chemical, Inc. (Passof et al. 1974, Marsh et al. 1974). In this study we evaluated deer mouse consumption of bitterbrush seed treated with these chemicals and standard Endrin treatments.

\section{Methods}

Our study was conducted in several stages. Initially, the four repellents named above were evaluated for reduction of bitterbrush seed consumption by deer mice. The initial repellent evaluation showed $9 \%$ ANTU to be the most effective repellent; consequently, 6 and $12 \%$ concentrations of $\Lambda \mathrm{NTU}$ were then evaluated. ANTU treated seed pretreated with thiourea, a suggested pregermination treatment for spring seeded bitterbrush (Pearson 1957), was also tested for deer mouse acceptance. To test consistency of deer mouse acceptance of $9 \%$ ANTU treated seed, a series of 10 feeding trials was conducted over a 3-year period. Finally, to standardize study results, deer mouse consumption of seed coated with $9 \%$ ANTU and seed coated with 1 and $0.5 \%$ Endrin was compared. Germination tests were also made to determine the effect of the adhesive, repellents, and thiourea on the rate and percentage of bitterbrush seed germination.

\section{Seed Treatments}

Hulled bitterbrush seeds were coated with an adhesive, Rhoplex AC-33 (stock solution diluted 1 to 3 with water), and one of the tested repellents. Seeds were treated in 200 -g lots (approximately 8,000 seeds) to insure uniform coating of individual seeds. For each lot, the required a mount of repellent was added to $66 \mathrm{~g}$ of adhesive. The adhesive and repellent mix was added to the seed and stirred until seed separation occurred. Seeds were then spread out to air-dry. Seeds were treated with either $3 \%$ Mestranol $(3 \mathrm{~g} / 100 \mathrm{~g}$ seed); 9\% R55; 9\% Red Squill; 6, 9, and $12 \%$ ANTU; or 0.5 or $1 \%$ Endrin.

In five additional seed treatments, seeds were first soaked in a $3 \%$ solution of thiourea for 20 minutes (Pearson 1957) and air-dricd. Treated seeds were then divided into five groups-one uncoated, the others coated with Rhoplex alone or with Rhoplex and a repellent (9\% ANTU, 0.5\% Endrin, 1\% Endrin).

Bitterbrush seed were initially treated with repellent at $9 \%$ of seed weight because this concentration gave the same amount of surface coverage (approximately $0.004 \mathrm{~g} / \mathrm{cm}^{2}$ ) as the successful $4 \%$ ANTU treatment of Douglas-fir seed (Passof et al. 1974). Mestranol was tested at $3 \%$ because this was the highest concentration that appeared even remotely economically feasible for field planting ( $\$ 32$ for the Mestranol + seed cost $/ \mathrm{kg}$ seed). Endrin, at 0.5 and $1 \%$ concentrations, is a standard repellent treatment ( $\mathrm{Radwan}$ et al. 1970). All repellent concentrations are approximations as some repellent loss is inherent in the seed coating procedure (Radwan et al. 1970).

\section{Feeding Trials}

Repellent treated bitterbrush seeds were fed to individually 
caged mice to determine the reduction in seed consumption over untreated seed. Mice used in the feeding trials were all trapped in bitterbrush dominant plant associations in the Sierra Nevada foothills and transferred to animal holding rooms at the University of Nevada Reno.

Mice were held for 7 days prior to testing to allow them to adapt to their new surroundings and food (Lab Chow). A surplus of water and Lab Chow was provided to the mice throughout their captivity, including during repellent feeding trials. Providing additional food choices is in line with EPA (1975) repellent testing guidelines and is consistent with field conditions; obviously other food must be available on sites prior to seeding if deer mice are already present.

Only those mice that consumed 200 or more untreated bitterbrush seed per night in individual feeding tests were used. Thus, the study was not confounded by differences in preference for bitterbrush seed among test mice.

Six or more mice were used as replicates for each repellent treatment. Each mouse was fed 200 treated or untreated bitterbrush seeds on each of 6 consecutive days. Seeds were given to the mice at $1600 \mathrm{~h}$ and the number of seeds consumed by each mouse was recorded at $0800 \mathrm{~h}$ the next day. Cages were checked for hoarded or dropped seed, but this rarely occurred. If a mouse died during a test, those results were discarded and an additional mouse tested until a total of 6 or more mice had completed that specific feeding trial.

Mean numbers of seed consumed per day for the fifth and sixth days (combined) of each feeding trial were compared in a one-way analysis of variance. If the analysis showed a significant difference $(P=0.05)$ among seed treatments, Hartley's sequential method of testing was used to delineate significantly $(P=0.05)$ different treatments (Snedecor 1956).

\section{Germination Tests}

Thirteen seed treatments were run in germination tests. Seed treatments are listed in Table 1. Four replicates of 100 bitterbrush seeds each were used in testing germination of seed in each treatment. Those seed treatments not receiving a thiourea pretreatment were stratified at $10^{\circ} \mathrm{C}$ for 2 weeks as prescribed by Young and Evans (1976). Seeds receiving a thiourea treatment wcre soaked in a 3\% thiourea solution for 20 minutes, drained, and air-dried (Pearson 1957). Replicates of each treat ment were placed on filter paper in individual petri dishes. All seed treatments (thiourea treated and stratified) were watered and placed in a germination chamber at $15^{\circ} \mathrm{C}$. Seeds were watered with a $0.1 \%$ fungicide solution (Captan) to reduce seed loss to pathogens as had occurred in earlier studies (Young and Evans 1976). Germinate counts were made weekly for 7 weeks. Seeds were considered to have germinated when a radicle $>1 \mathrm{~cm}$ in length was present.

Germinates at 21 and 49 days were run in separate analysis of variance tests to determine if there was a significant $(P=0.1)$ difference in germination among seed treatments.

Table 1. Seed treatments tested for germination response.

Stratified seed treatments

$\left(1^{\circ} \mathrm{C}\right)$

Control (no adhesive)

Adhesive coating (Rhoplex)

ANTU $^{1}$ ( 9 percent)

Endrin ( 1 percent)

Endrin (0.5 percent)

Red Squill ( 9 percent)

R55 ( 9 percent)

Mestranol (3 percent)

'All repellent treatments have an adhesive coating. ANTU = alphanaphthylthiourea Nine percent $=$ amount of repellent on the seed expressed as a percent of seed weight.

\section{Results and Discussion}

We found mice selected for testing could consume an average of 300 untreated seeds per night. Since only 200 treated seeds were provided to the mice each day, our results are a conservative estimate of the total possible reduction in seed consumption. Determination of the relative effectiveness of the tested repellents is unaffected since not all of the treated seeds were consumed.

In the initial feeding trial with the four test repellents, deer mice ate all untreated seed, but consumed 80 to $90 \%$ fewer seeds treated with $9 \%$ ANTU. ANTU (9\%) was far superior to $3 \%$ Mestranol, $9 \%$ R55, and 9\% Red Squill in reducing deer mice consumption (Fig. 1). Mestranol was superior to R55 in reducing deer mouse consumption of bitterbrush seed as also reported by Couch and Radwan (1971) for Douglas-fir seed.

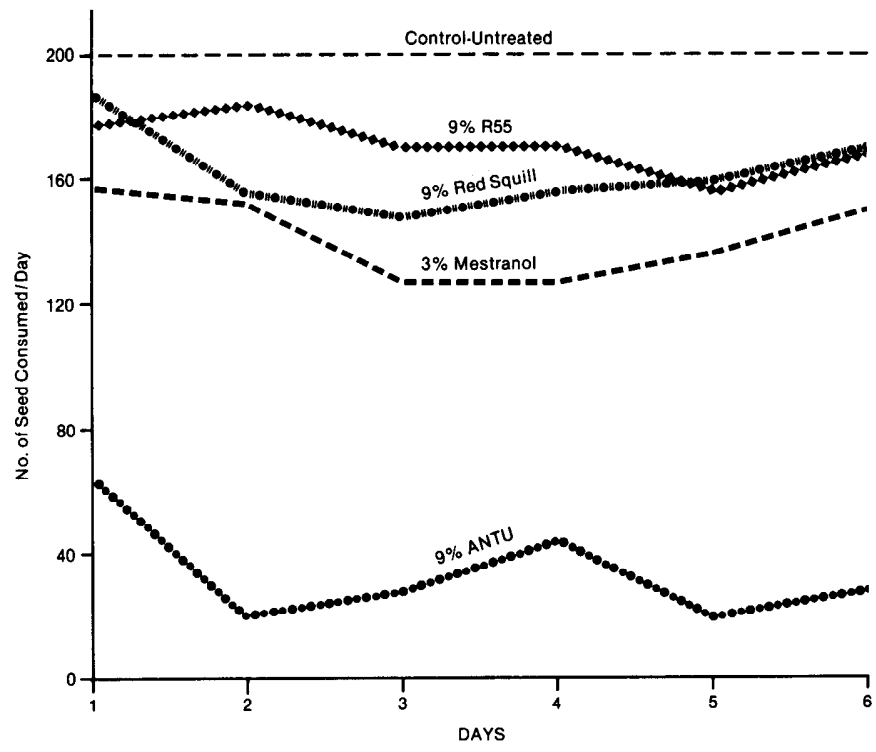

Fig. 1. Average number of bitterbrush seed consumed each day by deer mice when seed was coated with 9 percent ANTU, 3 percent mestranol, 9 percent Red Squill, 9 percent R55, or left untreated. Number of untreated seed consumed greater than $200(\hat{x} \simeq 300)$ when unlimited number of untreated seed provided.

Deer mouse mortality rates were higher in the ANTU fceding trials than the other three treatments. Approximately one-third of the mice fed seed treated with $9 \%$ ANTU died during the feeding trials, one-fourth of the mice fed R55 treated seed died, but none died when fed seed treated with Red Squill or Mestranol. A high mortality rate may be of some advantage on sites where deer mice cannot rapidly reinvade the treated area, but on other sites a stable population of mice conditioned against consuming repellent treated seed may be more desirable (Spencer 1954).

In testing different concentrations of ANTU, we found that $9 \%$ ANTU was the most efficient in reducing bitterbrush seed consumption. In a summer feeding trial, the $12 \%$ concentration of ANTU was no better than the $9 \%$ concentration in reducing deer mouse consumption of bitterbrush seed (i.e., $.05 \%$ ). The $6 \%$ concentration reduced seed consumption by only $25 \%$.

Deer mice consistently consumed less seed soaked in $3 \%$ thiourea and coated with $9 \%$ ANTU than seed coated with $9 \%$ ANTU alone (Fig. 2), but differences were not significant $(P=0.5)$. The $3 \%$ thiourea pregermination treatment reduced deer mouse predation of bitterbrush seed, but not as much as the ANTU coating. Thiourea was not tested as a repellent coating because of its possible carcinogenic effects on workers (U.S. Department of Health, Education and Welfare, 1974). Dust sloughing off thiourea coated seed could be an extreme health hazard in the preparation, transportation, and planting of the treated seed. Hazards to personnel should be reduced when seeds are only soaked in a thiourea solution as 


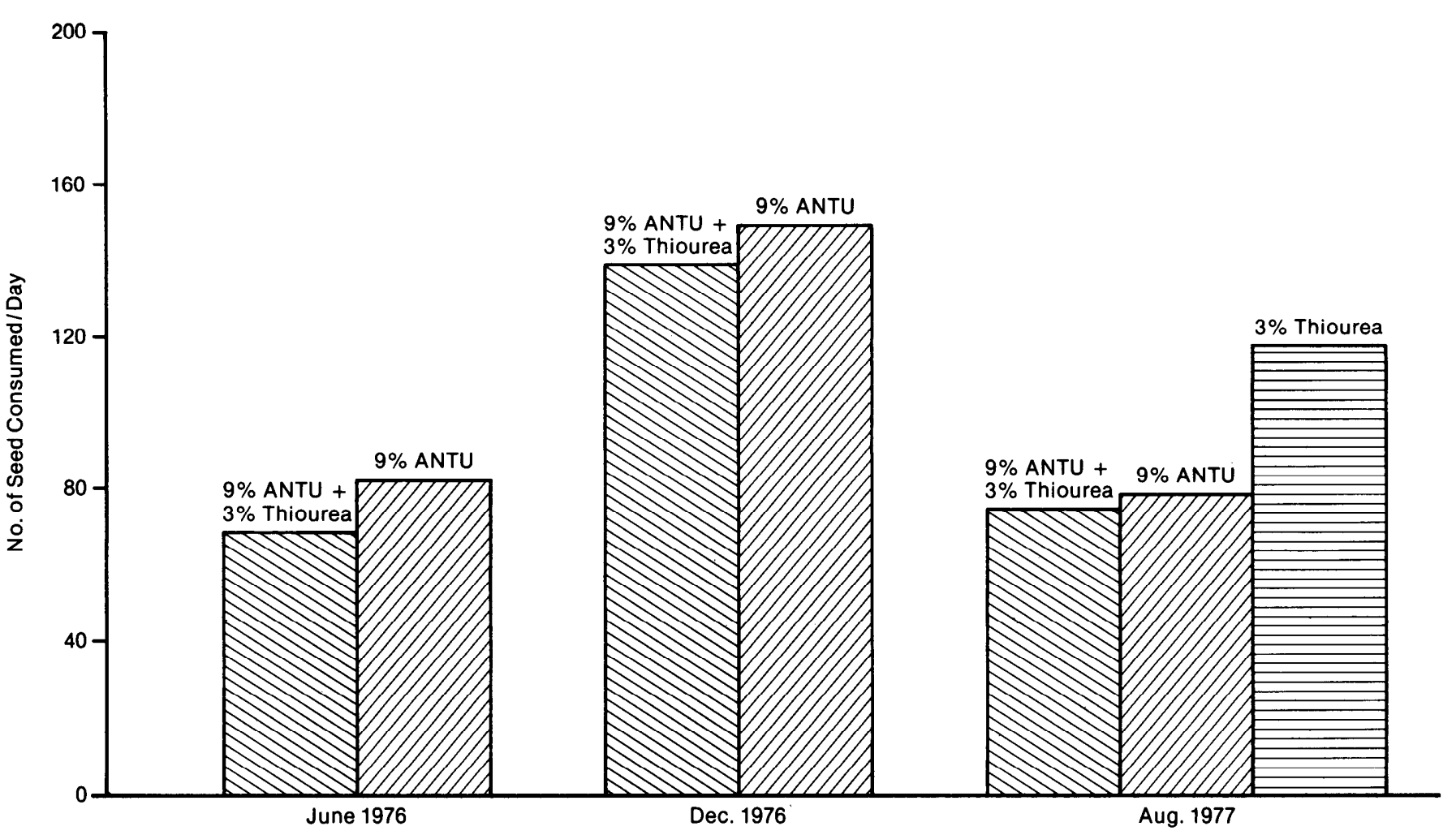

Fig. 2. Deer mouse consumption of bitterbrush seed treated with 9 percent alpha-naphthylthiourea, ANTU, 9 percent ANTU 3 percent thiourea, or 3 percent thiourea. Mean seed consumption for fith and sixth day of feeding trials is presented here to reflect the stabilized seed consumption rate (see Fig. 1).

personal contact with the undiluted substance is minimized. The health hazard of thiourea treated seed has not been determined; therefore seed must be handled with caution.

The ANTU treatment reduced mean deer mouse seed consumption to $\simeq 1 \mathrm{seed} / \mathrm{mouse} / \mathrm{night}$ in some tests, but was less effective, $\simeq 150$ seed consumed $/$ mouse/night in others (Table 2 ). The cause of variation in ANTU acceptance is unknown, but since feeding trial conditions (temperature and food) were generally constant we speculate changes in animal physiology and small differences in seed coating are responsible.

Endrin in 0.5 and $1 \%$ concentrations reduced deer mouse consumption of bitterbrush seed more than the $9 \%$ ANTU seed treatment but the difference was not significant (Table 3). As reported earlier by Radwan et al. (1970), deer mouse mortality (one-quarter of test

Table 2. Average number of $9 \%$ ANTU treated bitterbrush seed consumed per mouse day in different feeding trials.

\begin{tabular}{lccc}
\hline \hline & \multicolumn{3}{c}{ Number of seed consumed / mouse/day } \\
\cline { 2 - 4 } Feeding trial dates & $\ddot{x}$ seed $^{1}$ & $S_{\mathrm{D}}$ & $C V$ \\
\hline & & (seed) & $(\%)$ \\
1976: & 1 & 1.0 & 100 \\
February ${ }^{2}$ & 36 & 29 & 80 \\
May & 82 & 27 & 32 \\
June & 147 & 49 & 33 \\
December & & & \\
1977: & 90 & 51 & 56 \\
February & 50 & 33 & 66 \\
March & 88 & 71 & 80 \\
June & 76 & 32 & 42 \\
August & & & \\
1979: & 43 & 16 & 37 \\
February & 68 & 50 & 73 \\
May & 68 & 39 & 57 \\
All tests combined & &
\end{tabular}

${ }_{1} \bar{x}=$ mean, $S_{\mathrm{D}}=$ standard deviation, and $\mathrm{CV}=$ coefficient of variation $\left(S_{\mathrm{D}} \mathrm{D} / \overrightarrow{\mathrm{X}}\right) 100$. 2Pilot study, only four mice tested. mice) occurred when fed Endrin (1\%) treated seed. However, in our tests no mice died when fed 0.5 percent Endrin. Although ANTU (9\%) is less effective than Endrin ( 0.5 and $1 \%)$ in protecting bitterbrush seed from predation, this may be irrelevant because of restrictions on the use of Endrin.

Table 3. Number of seed consumed per mouse per day when seed coated with $9 \%$ ANTU, $1 \%$ Endrin, or $0.5 \%$ Endrin.

\begin{tabular}{lccc}
\hline \hline Repellent & $X^{1}$ & $S D$ & $\mathrm{~N}^{2}$ \\
\hline ANTU (9\%) & 55 & 38 & 12 \\
Endrin (0.5\%) & 35 & 27 & 12 \\
Endrin (1\%) & 29 & 23 & 9 \\
\hline
\end{tabular}

'Mean seed consumption for fifth and sixth day of the feeding trials is presented here to reflect the stabilized seed consumption rate (fig. 1).

${ }^{2} \mathrm{~N}=$ number of mice tested.

\section{Germination}

Seed treated with $9 \%$ ANTU had greater germination after 21 and 49 days than other stratified seed treatments. Endrin and all other repellents depressed germination of stratified seed (Table 4). Endrin's inhibitory effect on germination of conifer seed has been previously reported by Fraser (1973).

The thiourea presoak treatment increased total germination and germination vigor of seeds over stratified seeds in all comparisons tested. This difference in germination between thiourea and stratified treated bitterbrush seed was reported earlier by Evans and Young (1977). Seed treated with thiourea alone had the highest and most rapid germination of any seed treatment. Seed pretreated with thiourea and Endrin $(0.5$ and $1 \%)$ had greater germination than seed treated with ANTU (9\%) and thiourea.

The adhesive coating (Rhoplex) inhibited germination of both stratified and thiourea treated seed. Thiourea alone and in combination with Endrin ( 0.5 and $1 \%$ ), and ANTU alone appear to reduce the inhibiting effects of the adhesive. A more suitable adhesive should be used in future tests. 
Table 4. Percent germination at $15^{\circ} \mathrm{C}$ of bitterbrush seed following seed treatment.

\begin{tabular}{lll}
\hline & \multicolumn{2}{c}{ Mean germination percent } \\
\cline { 2 - 3 } Seed treatments & After 21 days & After 49 days \\
\hline Seed stratified' & $25^{\mathrm{cd} 2}$ & $28^{\mathrm{de}}$ \\
Control & $18^{\mathrm{e}}$ & $19^{\mathrm{e}}$ \\
Adhesive (Rhoplex) & $37^{\mathrm{bd}}$ & $39^{\mathrm{d}}$ \\
ANTU (9\%) & $11^{\mathrm{e}}$ & $13^{\mathrm{e}}$ \\
Endrin (1\%) & $15^{\mathrm{e}}$ & $16^{\mathrm{e}}$ \\
Endrin (0.5\%) & $11^{\mathrm{e}}$ & $13^{\mathrm{e}}$ \\
Red Squill (9\%) & $16^{\mathrm{e}}$ & $20^{\mathrm{e}}$ \\
R55 (9\%) & $16^{\mathrm{e}}$ & $21^{\mathrm{e}}$ \\
Mestranol (3\%) & & \\
Thiourea treated & $79^{\mathrm{a}}$ & $92^{\mathrm{a}}$ \\
Control & $36^{\mathrm{bcd}}$ & $67^{\mathrm{bc}}$ \\
Adhesive (Rhoplex) & $23^{\mathrm{de}}$ & $56^{\mathrm{c}}$ \\
ANTU (9\%) & $43^{\mathrm{be}}$ & $81^{\mathrm{ab}}$ \\
Endrin (1\%) & $45^{\mathrm{b}}$ & $70^{\mathrm{bc}}$ \\
Endrin (0.5\%) & & \\
\hline
\end{tabular}

'Seed stratified at $1^{\circ} \mathrm{C}$ for 2 weeks following seed treatment (Young and Evans 1976) ${ }^{2}$ For each column, seed germination percentages that a re not followed by the same letter are significantly different $(\mathrm{P}=0.05)$. For example, $\mathrm{a}=$ significantly different from $b$, not from $a b$.

${ }^{3}$ ANTU $=$ alpha-naphthylthiourea

${ }^{4}$ Seed soaked in $3 \%$ thiourea solution (Pearson 1957)

\section{Conclusions}

ANTU (Alpha-naphthylthiourea) applied as a seed repellent at 9\% of seed weight reduced deer mice predation of bitterbrush seed more than 9\% R55, 9\% Red Squill, or 3\% Mestranol. Deer mouse consumption of ANTU treated seed varied from near 0 to 150 seed/mouse/night among the 10 separate feeding trials. Deer mice consumed more untreated seed $(\dot{x} \simeq 300 \mathrm{seed} /$ mouse/night) than ANTU treated seed in all feeding trials.

Seed pretreated with a $3 \%$ thiourea soak to hasten germination (Pearson 1957) was slightly repellent to deer mice. The combination of a $3 \%$ thiourea soak treatment and a $9 \%$ ANTU coating gave increased repellency over either treatment alone.

Germination of seed treated with ANTU and then stratified was improved over seed only subjected to stratification. The ANTU seed treatment reduces germination of seed subjected to a thiourea presoak treatment. Because of the large number of seeds protected from mice predation, the reduction in germination of thiourea treated seed does not invalidate the use of ANTU.

Feeding and germination trials indicate ANTU should be field tested as an interim alternative to Endrin in the protection of bitterbrush seed from deer mice. As we encountered variability in ANTU acceptance under controlled environmental conditions, it seems logical to expect increased variability in ANTU effectiveness under field conditions, as was found in field trials of Endrin. The true worth of the ANTU seed treatment can only be determined by testing ANTU treated seed under a wide range of environmental conditions.

\section{Literature Cited}

Brown, E.R., and C.F. Martinsen. 1959. Browse planting for big game in the State of Washington. Washington State Game Comm. Biol. Bull. 12, $63 \mathrm{p}$.

Casebeer, R.L., 1954. The use of tetramine in bitterbrush revegetation. J. Forest. 52:829-830.

Crouch, G.L., and J.A. Radwan. 1971. Evaluation of R55 and mestranol to protect Douglas-fir seed from deer mice. U.S. Dep. Agr. Forest Serv. Res. Note. PNW-170, 6 p. Pacific Northwest Forest and Range Exp. Sta., Portland, Ore.

Evans, J. 1974. Pesticides and forest wildlife in the Pacific Northwest. p. 205-219. In: Symp. Proc. Wildlife and Forest Management in the Pacific Northwest. Ed. H.C. Black, Sch. Forest, Oregon State Univ., Corvallis.

Evans, R.A., and J.A. Young. 1977. Bitterbrush germination with constant and alternating temperatures. J. Range Manage. 30(1):30-32.

Fraser, T.W. 1973. Seed treatments (including repellents). p. 77-90. In: Direct Seeding Symposium, Timmins, Ontario, Sept. 11-13, 1973. Proc. Dep. Environ. Can. Forest Serv. Pub. No. 1339.

Holmgren, R.C., and J.V. Basile. 1959. Improving southern Idaho deer winter ranges by artificial revegetation. State Idaho Dep. Fish and Game Wildl. Bull. 3. 61 p.

Kverno, N.B., and H.D. Hartwell. 1957. Progress report-Pacific Northwest $1955-56$ and 1956-57 experimental seeding studies. 50 p. U.S. Dep. Interior, Bur. Sport Fish and Wildl.

Lindsey, G.D., R.M. Anthony, and J. Evans. 1974. Mcstranol as a repellant to protect Douglas-fir seed from deer mice. p. 272-279. In: Proc. Sixth Vertebrate Pest Conf., Anaheim, Calif.

Marsh, R.E., P.C. Passof, and W.E. Howard. 1974. Anticoagulants and Alpha-naphthylthiourea to protect conifer seeds. p. 75-83. In: Symp. Proc. Wildlife and Forest Management in the Pacific Northwest. Ed. H.C. Black, Sch. Forest, Oregon State Univ., Corvallis.

Nord, E.C. 1965. Autecology of bitterbrush in California. Ecol. Monogr. 35:307-334.

Passof, P.C., R.E. Marsh, and W.E. Howard. 1974. Alphanaphthylthiourea as a conditioning repellent for protecting conifer seed. p. 280-292. In: Proc. Sixth Vertebrate Pest Conf., Anaheim, Calif.

Pearson, B.0. 1957. Bitterbrush seed dormancy broken with thiourea. J. Range Manage. 10:41-43.

Radvanyi, A. 1970. A new coating treatment for coniferous seeds. Forest Chron. 46(5):406-408.

Radwan, M.A., G.L. Crouch, and W.D. Ellis. 1970. Impregnating and coating with Endrin to protect Douglas-fir seed from rodents. U.S. Dep. Agr. Forest Serv. Res. Pap. PNW-94, 17 p. Pacific Northwest Forest and Range Exp. Sta., Portland, Ore.

Snedecor, E.W. 1956. Statistical Mcthods Applied to Experiments in Agriculture in Biology. 534 p. Fifth ed., Iowa State Univ. Press. Ames.

Spencer, D.A. 1954. Rodents and direct seeding. J. Forest. 52:824-826.

U.S. Department of Health, Education and Welfare. 1974. Toxic substances list. H.E. Christensen and T.T. Luginbyhl, eds. HEW Publ. (NIOSH) 74-134, $802 \mathrm{p}$.

U.S. Environmental Protection Agency. 1975. Pesticide programs. Guidelines for registering pesticides in the United States. Fed. Reg. (FRL 375-1) 1(40):26802-26928.

Young, J.A., and R.A. Evans. 1976. Stratification of bitterbrush seeds. J. Range Manage. 29:421-425. 